\title{
RELAP5 SIMULATION FOR SEVERE ACCIDENT ANALYSIS OF RSG-GAS REACTOR
}

\author{
Andi Sofrany Ekariansyah, Endiah P. Hastuti, Sudarmono \\ Center for Nuclear Reactor Technology and Safety-BATAN, Puspiptek Area, Setu, Tangsel, 15310 \\ Email: andi_se@batan.go.id \\ Diterima editor: 9 Januari 2018 \\ Diperbaiki: 23 Januari 2018 \\ Disetujui untuk publikasi: 24 Januari 2018
}

\begin{abstract}
RELAP5 SIMULATION FOR SEVERE ACCIDENT ANALYSIS OF RSG-GAS REACTOR. The research reactor in the world is to be known safer than power reactor due to its simpler design related to the core and operational chararacteristics. Nevertheless, potential hazards of research reactor to the public and the environment can not be ignored due to several special features. Therefore the level of safety must be clearly demonstrated in the safety analysis report (SAR) using safety analysis, which is performed with various approaches and methods supported by computational tools. The purpose of this research is to simulate several accidents in the Indonesia RSG-GAS reactor, which may lead to the fuel damage, to complement the severe accident analysis results that already described in the SAR. The simulation were performed using the thermal hydraulic code of RELAP5/SCDAP/Mod3.4 which has the capability to model the plate-type of RSG-GAS fuel elements. Three events were simulated, which are loss of primary and secondary flow without reactor trip, blockage of core subchannels without reactor trip during full power, and loss of primary and secondary flow followed by reactor trip and blockage of core subchannel. The first event will harm the fuel plate cladding as showed by its melting temperature of $590{ }^{\circ} \mathrm{C}$. The blockage of one or more subchannels in the one fuel element results in different consequences to the fuel plates, in which at least two blocked subchannels will damage one fuel plate, even more the blockage of one fuel element. The combination of loss of primary and secondary flow followed by reactor trip and blockage of one fuel element has provided an increase of fuel plate temperature below its melting point meaning that the established natural circulation and the relative low reactor power is sufficient to cool the fuel element.
\end{abstract}

Keywords: loss of flow, blockage, fuel plate, RSG-GAS, RELAP5

\begin{abstract}
ABSTRAK
SIMULASI RELAP5 UNTUK ANALISIS KECELAKAAN PARAH PADA REAKTOR RSG-GAS. Reaktor riset di dunia diketahui lebih aman dari pada reaktor daya karena desainnya yang lebih sederhana pada teras dan karakteristika operasinya. Namun demikian, potensi bahaya reaktor riset terhadap publik dan lingkungan tidak bisa diabaikan karena beberapa fitur tertentu. Oleh karena itu, level keselamatan reaktor riset harus jelas ditunjukkan dalam Laporan Analisis Keselamatan (LAK) dalam bentuk analisis keselamatan yang dilakukan dengan berbagai macam pendekatan dan metode dan didukung dengan alat komputasi. Tujuan penelitian ini adalah untuk mensimulasikan beberapa kecelakaan parah pada reaktor RSG-GAS yang dapat menyebabkan kerusakan bahan bakar untuk memperkuat hasil analisis kecelakaan parah yang sudah ada dalam LAK. Simulation dilakukan dengan program perhitungan RELAP5/SCDAP/Mod3.4 yang memiliki kemampuan untuk memodelkan elemen bahan bakar tipe pelat di RSG-GAS. Tiga kejadian telah disimulasikan yaitu hilangnya aliran primer dan sekunder dengan kegagalan reaktor untuk dipadamkan, tersumbatnya beberapa kanal pendingin bahan bakar pada daya penuh, dan hilangnya aliran primer dan sekunder yang diikuti dengan tersumbatnya beberapa kanal pendingin bahan bakar setelah reaktor padam. Kejadian pertama akan membahayakan pelat bahan bakar dengan naiknya temperatur kelongsong hingga titik lelehnya yaitu $590{ }^{\circ} \mathrm{C}$. Tersumbatnya satu atau beberapa kanal pada satu elemen bahan bakar menyebabkan konsekuensi yang berbeda pada pelat bahan bakar, dimana paling sedikit tersumbatnya 2 kanal akan merusak satu pelat bahan bakar, apalagi tersumbatnya satu elemen bahan bakar. Kombinasi antara hilangnya aliran pendingin primer dan sekunder yang diikuti dengan tersumbatnya satu kanal bahan bakar setelah reaktor dipadamkan menyebabkan naiknya temperatur kelongsong di bawah titik lelehnya yang berarti sirkulasi alam yang terbentuk dan daya yang terus turun cukup untuk mendinginkan elemen bahan bakar.
\end{abstract}

Kata kunci: kehilangan aliran, penyumbatan, pelat bahan bakar, RSG-GAS, RELAP5

DOI: $10.17146 / \operatorname{tdm} .2018 .20 .1 .4040$ 


\section{INTRODUCTION}

In the nuclear reactor, fuel elements are the source of energy generated from continuous fission process. Its energy in the fuel is then transferred to the coolant by various mechanism such as conduction, convection, and radiation. That heat energy removal must enable the coolant to cool the fuel elements, therefore a complete coolant flow along the fuel length should be ensured. In the research reactor, the use of nuclear fuel elements is normally to generate neutron for various purposes, such as for research, training, education, radioisotope production, neutron radiography and materials testing [1]. By design, research reactors are simpler than power reactors. The simplicity is showed by the core characteristics such as lower operation temperatures (low power level), less fuel, and less fission products accumulation [2]. That simpler design is however covered by more highly enriched uranium, typically around $20 \%$ of U-235, and higher power density in the core. The cooling of the fuel elements is not different than power reactors, as forced cooling is normally considered for high-power research reactors. Most common design of research reactors is pool-type reactor, light water cooled and moderated, and equipped by beryllium reflector, for which plate-type fuel elements are placed in the pool bottom as in the case of multipurposes research reactor of G.A. Siwabessy (RSG-GAS) in Indonesia. Even with the simpler design and low power level, potential hazard of research reactor to the public and the environment can not be ignored because of several special features such as numerous start and shutdown, power levels variation, transfers of irradiated materials, etc [3]. Those potential hazards might be initiated by possible transient and accident events, which in theory can take place during the life time of RSG-GAS reactor, for which their consequences have been described in the Safety Analysis Report [4]. The report describes the capability of RSG-GAS protection and mitigation systems dealing with the so called design basis accident (DBA), which is from thermal hydraulic aspect demonstrated by various codes such as NATCON, COOLOD-N, and PARET-ANL. All safety analysis results point out that determined safety margin, such as flow instability margin, does not exceeded, meaning that the postulated accidents can be prevented and the most notable indication is that the fuel elements are sufficiently cooled. Some postulated DBA have also been analyzed using codes to enhance the analysis results in the report as the case of LOFA [5] and LOCA [6]. Beyond of that, the safety analysis also considere the worst consequence of DBA causing the maximum radiological consequence, in which one fuel element consisting of 21 fuel plates is damaged or melted due to overheat resulted from blockage of fuel cooling canal [4].

The event sequences and mechanism of the melting of fuel element are well described in the report, however research related to the code used, methodology, and model simulation in the references are hardly to find. One reference regarding the event was an analysis of partial coolant channel blockage accident in the oxide and silicide core design of RSG-GAS [7] in 1999, which did not represent the case of fuel melt in the report. On the other hand, a simulation of fuel channel blockage has been conducted using Finite Element Method on Tehran Research Reactor (TRR-5) which has a similar plate-type fuel elements with those on RSG-GAS core [8]. Related to the above topic, the purpose of this research is to simulate several events in the RSG-GAS reactor leading to the fuel damage due to the lack of cooling in the core to complement the severe accident analysis results in the report. The simulation were performed using the thermal hydraulic code of RELAP5/SCDAP/Mod3.4 which has capability to model the plate-type of RSG-GAS fuel elements. The event selected is not limited to the fuel channel blockage but extended to the loss of offsite power, which induces the loss of complete flow accident followed by the failure of protection system to shutdown the reactor. That so called multiple failures without scram is one hypothetical accident scenario to eliminate the cooling of the fuel element leading to the fuel damage besides the LOCA below the core [9]. The results of this simulation will be used to analyse the condition of fuel plate in term of its cladding temperature and the void formation in the core subchannel as the indication of fuel overheating and loss of fuel cooling. At the end, the analysis will contribute to the understanding of severe accident in the RSG-GAS and enhancing its operational safety. 


\section{DESCRIPTION OF RSG-GAS CORE}

The RSG-GAS reactor core configuration consists of $10 \times 10$ core grid positions, in which three types of square shaped elements with $100 \times 100 \mathrm{~mm}$ are placed. Those elements are 40 standard fuel elements (FE), 8 control fuel elements (CE), and the rest of elements in form of Beryllium elements surrounded by two-sides of block refector [10]. For the standard fuel element, 21 plates are installed, whereas 15 plates are on the control fuel elements, in which each plate contains $19.7 \%$ enriched uranium load. The fuel meat contains a mix of uranium silicide dispersed in aluminium matrix $\left(\mathrm{U}_{3} \mathrm{Si}_{2}-\mathrm{Al}\right)$ with the uranium meat density of $2,96 \mathrm{~g} / \mathrm{cm}^{3}$, which is surrounded by magnesium-aluminum alloy $\left(\mathrm{AlMg}_{2}\right)$ cladding material [11]. The cooling water to remove generated heat in the fuel elements flows downward between subchannels inside a fuel element and between sidelines of fuel elements due to forced convection driven by the primary cooling pumps. When the forced convection is lost, the flaps below the core will fall by gravity to enable an upward natural circulation driven by water density difference [12]. Figure 1 below presents the core configuration on the whole, each standard fuel element, each control fuel element, and the flow direction. The detail geometrical data of the core can be found in the Safety Analysis Report of the RSG-GAS reactor.

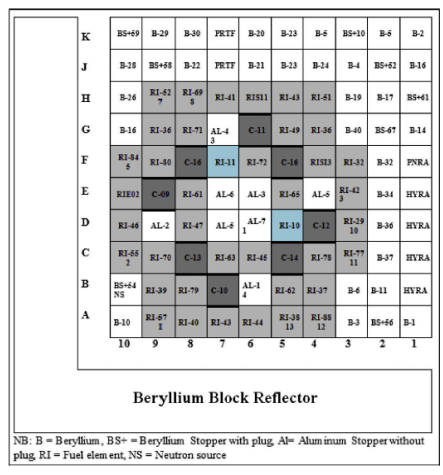

a

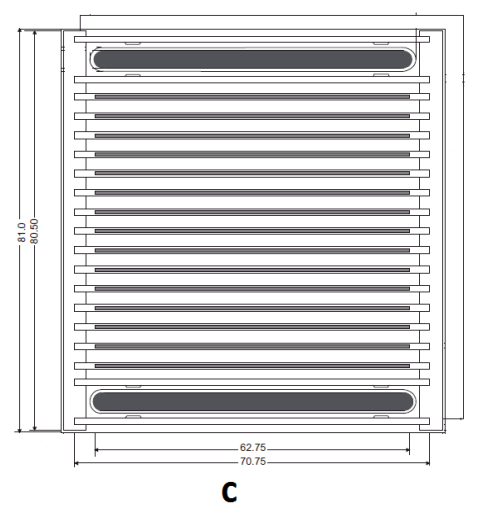

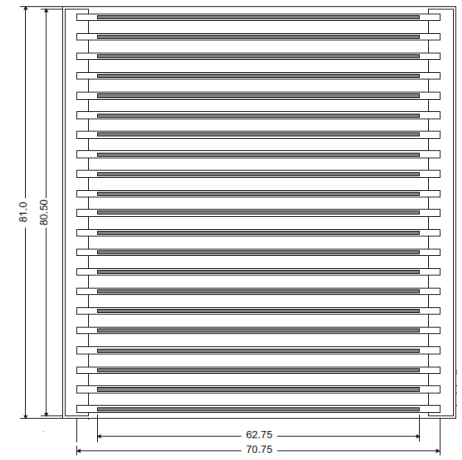

b

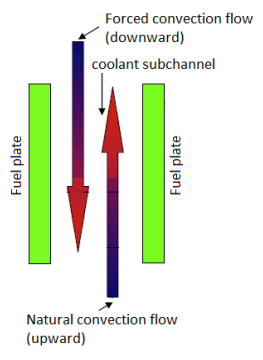

d

Figure 1. RSG-GAS core configuration showing: a. The entire core (top view), b. Standard fuel element (top view), c. Control fuel element (top view), d. Schematic of flow between 2 fuel plates (side view) [10, 13]

As illustrated in the Fig. 1, in total there are 960 fuel plates in the RSG-GAS core, in which the coolant flows between subchannel of the plates. The reactor cooling pumps of RSG-GAS delivers coolant flow with the total nominal mass flow of $860 \mathrm{~kg} / \mathrm{sec}$ to enter the subchannel of the fuel plates with the effective mass flow of $618 \mathrm{~kg} / \mathrm{second}$ on $0.6 \mathrm{~m}$ length. The mass flow rate between 2 fuel plates are differently calculated by other researchers and ranged from 0.517 to $0.936 \mathrm{~kg} / \mathrm{sec}$ [12]. The total power to be generated in the core is $30 \mathrm{MWt}$ providing an average power per plate of $31.25 \mathrm{kWt}$ from 960 fuel plates. The cooling water enters the core with the coolant temperature of $313.5 \mathrm{~K}\left(40.5^{\circ} \mathrm{C}\right)$ to be heated along the core with the average increased temperature of $11.8 \mathrm{~K}$ or $325.3 \mathrm{~K}\left(52.3{ }^{\circ} \mathrm{C}\right)$ in average for the outlet core temperature. The coolant pressure of the open 
pool is a function of atmospheric pressure, hydrostatic water pressure, and pressure due to forced convection with the operating core inlet pressure of 1.997 bar and core outlet pressure of 1.445 [6]. The above core characteristics are used in modelling the RSG-GAS in particular in the core and fuel element section for the preparation of severe accident simulation using RELAP5.

\section{RELAP5 NODALIZATION FOR SEVERE ACCIDENT ANALYSIS}

The reactor is operated with $30 \mathrm{MWt}$ power generated in the fuel plates of the core. In reality, that thermal power is not evenly distributed on all 960 plates, since an averaged distributed heat will result in inaccuracy of the calculated plate temperature. Practically, the core is divided into 3 major channels, representing the parallel coolant channels of the different fuel elements, which are the hot, average, and bypass channel [14]. The hot channel represents the fuel element channel, in which the maximum core temperature or the hottest fuel plate can occur, and the average channel represents the fuel element with the average core temperature. The bypass channel is simply the cooling channel in the beryllium elements. To characterize the power generated in the hot channel, a specific radial power peaking factor is determined, which in this case is 1.48 . The hot channel is determined to be the channels in one fuel element consisting of 21 plates. The power in the average channel is an average core power with the ratio of 1.0 as a relative power and generated in the rest of 47 fuel elements. To represent the axial distribution along the vertical plate, a value of axial peaking factor of 1.603 is used, which is distributed in 11 axial nodes. Those values and assumption has been used for the comparative assessment of the RSG-GAS reactor [10, 12]. The difference is that the hot core is modelled by integrating all 21 fuel plates into one heat structure in which the 22 subchannel flow areas were simplified into one subchannel. The hot core therefore becomes one heat structure and one channel with the radial peaking factor of 1.48 , whereas this research will focus on the model of each 21 individual fuel palates. The properties of fuel meat and cladding material are represented by the conductivity values as a function of temperature. Table 1 summarizes the thermal hydraulic parameter for modelling the core of the RSG-GAS as requested by the RELAP5 code.

Table 1. Thermal hydraulic parameters for modelling the core of the RSG-GAS required by the RELAP5 code.

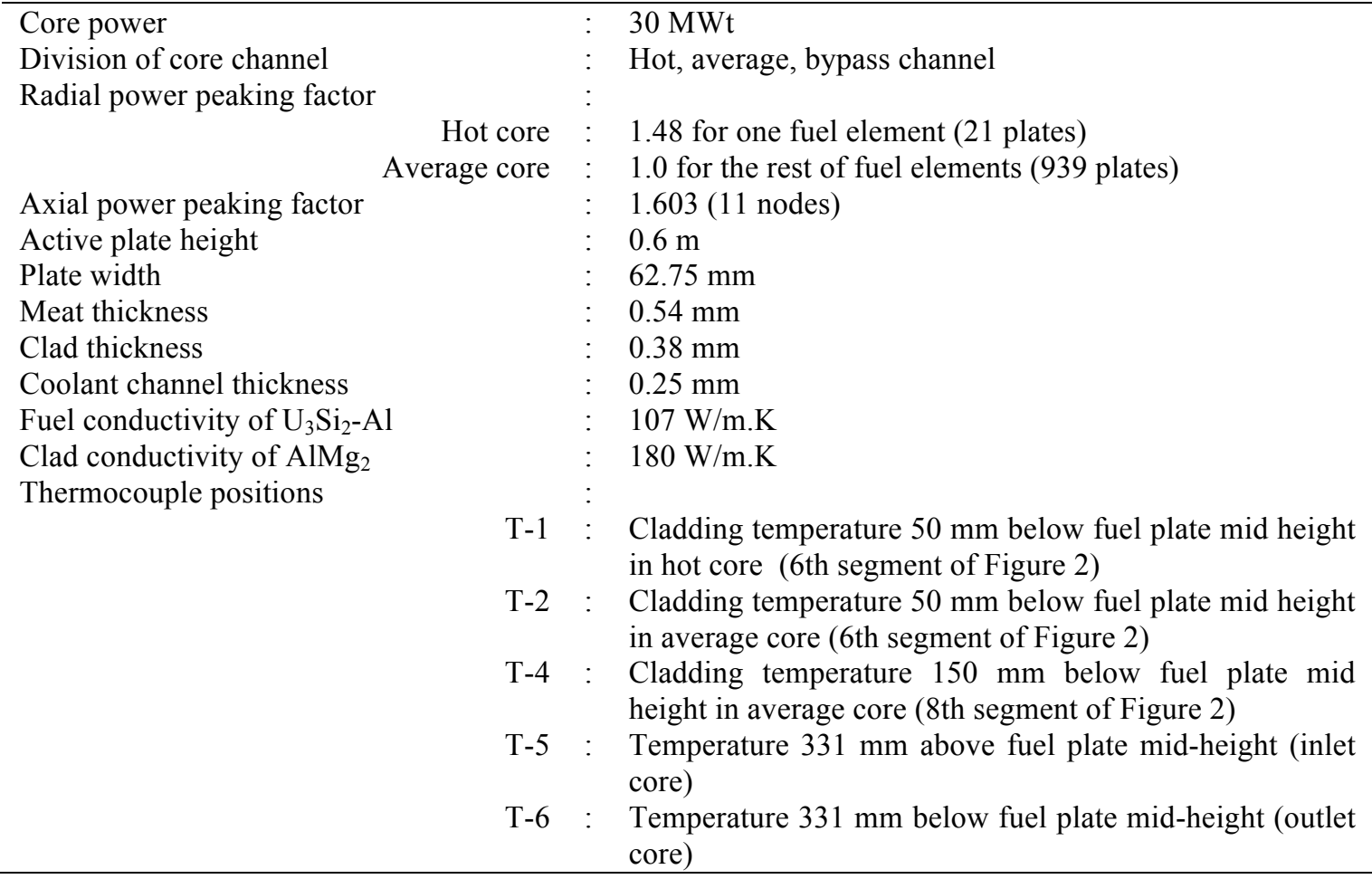


The plate temperature under consideration is the temperature on the surface of the plate cladding. The plate nodalization also enables the calculation of meat temperature. For that purposes, the plate is discretized into 7 nodes radially, in which the calculated cladding temperature are indicated in the $1^{\text {st }}$ node and and $7^{\text {th }}$ node showing the left and right side of the plate respectively. Figure 2 presents the nodalization scheme of one fuel element consisting of 21 plates and 22 subchannel in the y-direction and the nodes discretization in the $\mathrm{x}$-direction for one plate applied to all 21 plates. On this fuel element, a radial power peaking factor of 1.48 is applied to the fuel plates representing the heat flux in to hot channel. Other fuel elements are modelled as one united fuel plates having surface area of 939 plates with a radial power peaking factor of 1.0. To accomodate the 11 axial nodes distribution, each plate is divided into 10 axial segments equally. On each segment, a uniform temperature distribution is applied according to the each axial segment factor respectively. To validate the calculated cladding temperature, measured cladding temperatures from two Instrumented Fuel Elements, IFE RI-10 and IFE RI-11, are provided at several plate positions, in hot and average core as also the positions for inlet and outlet core temperature, in which the values can be seen in References [10,12]. The thermocouple positions are descriptive presented in Table 1 and visually in Figure 2.

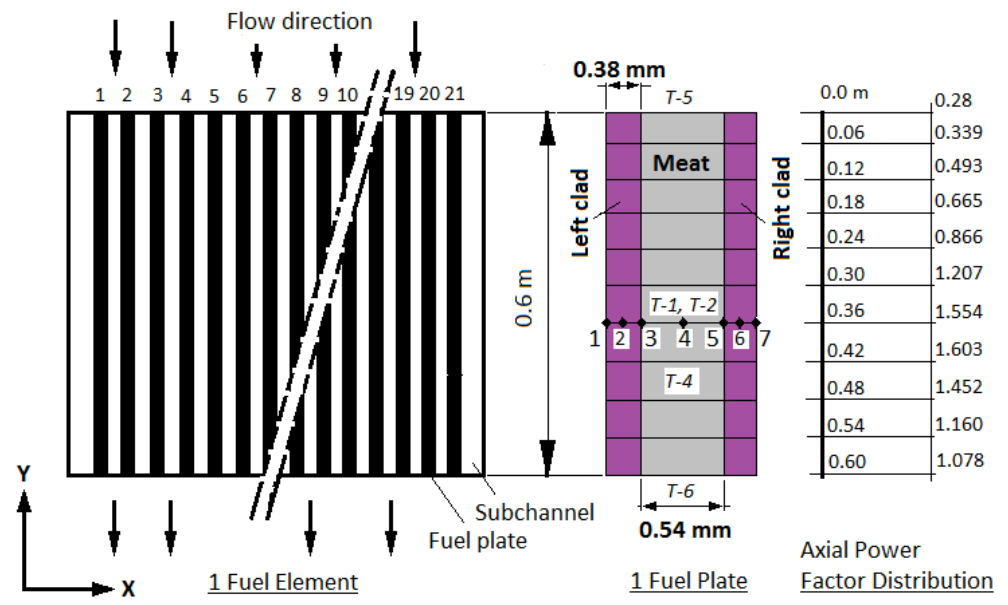

Figure 2. RELAP5 modelling of 1 fuel element representing hot channel, node discretization on 1 fuel plate, and axial power distribution along fuel plate (side view)

The fuel element modelling as presented in Figure 2 is so developed to enable analysis on phenomena occurring at each subchannel during various number of subchannel blockage. To analyse severe accident phenomena as showing by the increase of fuel cladding temperature, 2 main events are chosen after steady state simulation covering loss of complete flow and blockage of core subchannels. Those events are then divided into 3 initiating events:

- $\quad$ Loss of complete flow with reactor full power without reactor trip

- Blockage of one or more subchannels on one fuel element with reactor full power without reactor trip

- Loss of complete flow with reactor trip followed by blockage of one or more subchannels on one fuel element

\section{RESULTS AND DISCUSSION}

\section{Validation of cladding temperature during full power}

From the $30 \mathrm{MWt}$ generated by the core, $1 \%$ of reactor power is assumed conservatively generated in the Beryllium reflector due to neutron radiation and Gamma heating [4]. The rest of core power or $99 \%$ is generated in the fuel elements resulting in $29.7 \mathrm{MWt}$ core power. From the thermal hydraulic parameter showed in Table 1, the radial power peaking factor of 1.48 in hot core 
will result in the distribution of $29.7 \mathrm{MWt}$ in the $3.2 \%$ of power in the hot core and $95.8 \%$ of power in the average core. Taking consideration to the hot core, that power portion is divided equally at 21 fuel plates, in which the power of 1 plate is axially distributed according to the segment axial power factor distribution. The similar approach is also applied for the average core covering much more fuel plates. Table 2 presents the calculation results related to the cladding temperatures in the individual fuel plate after 1000 seconds RELAP5 steady-state simulation. Since there are 420 points of cladding temperatures, only 2 points in the $6^{\text {th }}$ segment of hot core representing the IFE RI-10 or T-1 will be presented. Those 2 points show the left and right side of each fuel plate. 3 fuel plates are taken for sample, which are $1^{\text {st }}$ plate, $11^{\text {th }}$ plate, and $21^{\text {st }}$ plate respectively. For the average core, the 2 points cladding temperatures are also in the $6^{\text {th }}$ segment or T-2 and $8^{\text {th }}$ segment or T-4 representing the IFE RI-11 respectively. Those calculated cladding temperatures will be compared with experimental results [10] and other RSG-GAS steady-state calculation using RELAP5, PARET-ANL, and MERSAT [12]. As further analysis, core inlet and outlet temperature as also HX inlet and outlet temperature are presented in the table.

Table 2. Cladding temperatures in the individual fuel plate and other parameters from RELAP5 steadystate simulation

\begin{tabular}{|c|c|c|c|c|c|c|}
\hline Core section & $\begin{array}{l}\text { Thermocouple } \\
\text { positions, (plate } \\
\text { number) }\end{array}$ & $\begin{array}{l}\text { Temperatures } \\
\text { (left/right) in } \\
{ }^{\circ} \mathrm{C}\end{array}$ & $\begin{array}{l}\text { Experiment } \\
\text { results } \\
\text { in }{ }^{\circ} \mathrm{C}[10]\end{array}$ & $\begin{array}{l}\mathrm{ARG} \\
\text { reactor } \\
\text { model } \\
\text { in }{ }^{\circ} \mathrm{C}[12]\end{array}$ & $\begin{array}{l}\text { GRE } \\
\text { reactor } \\
\text { model } \\
\text { in }{ }^{\circ} \mathrm{C}[12]\end{array}$ & $\begin{array}{l}\text { SYR } \\
\text { reactor } \\
\text { model } \\
\text { in }{ }^{\circ} \mathrm{C}[12]\end{array}$ \\
\hline Hot core & $\mathrm{T}-1,(1)$ & $90.93 / 90.99$ & 84.44 & 94.90 & 85.22 & 79.91 \\
\hline \multirow[t]{2}{*}{ (cladding) } & $\mathrm{T}-1,(11)$ & $91.39 / 91.39$ & & & & \\
\hline & $\mathrm{T}-1,(21)$ & 90.99 / 90.93 & & & & \\
\hline Average core & $\mathrm{T}-2$ & 73.89 & 74.21 & 77.70 & 71.26 & 72.50 \\
\hline (cladding) & $\mathrm{T}-4$ & 80.19 & 76.61 & 81.40 & 71.74 & 75.15 \\
\hline Core inlet & $\mathrm{T}-5$ & 35.7 & - & 39.70 & 40.00 & 40.00 \\
\hline Core outlet & T-6 & 44.53 & 51.88 & 52.90 & 49.41 & 52.23 \\
\hline HX inlet & - & 44.53 & 42.6 & 41.80 & - & - \\
\hline HX outlet & - & 35.7 & 35.4 & 35.60 & - & - \\
\hline
\end{tabular}

The calculation results indicate that the cladding temperature on a fuel plate, which is side by side with other fuel plate, is higher than that on the edge. On average, the cladding temperature by RELAP5 calculation is around $91.10{ }^{\circ} \mathrm{C}$ in the hot core or deviated approximately $7 \%$ with the measured data. The relative error will become smaller in the calculation of the average core. That deviation might be caused by many parameters as it is also visible on the other calculation results. In general, the fuel plate model by considering 21 plates is representative enough to be used for the next transient analysis.

\section{Cladding temperatures due to loss of complete flow with reactor full power without reactor trip}

The loss of complete flow event is an event, which is initiated by the failure of the reactor cooling pumps and secondary cooling pumps in the RSG-GAS reactor to operate. Such abnormal condition might be initiated by the loss of offsite power followed by the loss of diesel generator to supply emergency power. In normal condition, the loss of offsite power will be responded by the reactor protection system to trip the reactor by dropping the control elements. Since the Safety Analysis Report (SAR) ensured the safety of the fuel plates during the shutdown condition [4], an assumed failure of the shutdown system is made for this event. The event to be simulated will follow the scenario as described in the SAR as also already simulated through a benchmark activities [10, 15]. The difference is that the simulation will focus directly in the cladding temperature of the 21 fuel plates as previously modelled. After $1000 \mathrm{sec}$ simulation with $30 \mathrm{MWt}$ reactor power, in which 2 primary pumps and secondary pumps deliver coolant of $860 \mathrm{~kg} / \mathrm{sec}$ and $540 \mathrm{~kg} / \mathrm{sec}$ respectively, the pumps are tripped simultaneously. After several RELAP5 calculations, the core model with 21 plates and their subchannel could not produce the increase of cladding temperatures to the $\mathrm{AlMg}_{2}$ melting point of $590{ }^{\circ} \mathrm{C}$ [4] or $650{ }^{\circ} \mathrm{C}$ [16]. The calculation is stopped 
when the cladding temperature achieves the value of $345{ }^{\circ} \mathrm{C}$ in one of fuel plates as one particular subchannel experiencing two-phase flow condition, in which the pressure become very low. In order to obtain at least an estimation of cladding temperature based on the event, a change of model was conducted by integrating all 21 fuel plates into one heat structure in which the 22 subchannel flow areas were simplified into one subchannel. The hot core therefore becomes one heat structure and one channel with the radial peaking factor of 1.48. Figure 3 presents the results of calculation with the alternative hot core model after the loss of complete flow in $\mathrm{T}=0$ second. In addition to the T-1 thermocouple $\left(6^{\text {th }}\right.$ segment or T6), the cladding temperature in the upper segment $\left(1^{\text {st }}\right.$ segment or $\left.\mathrm{T}_{1}\right)$, the lowest segment $\left(10^{\text {th }}\right.$ segment or $\left.\mathrm{T}_{10}\right)$ and the segment with the highest axial factor $\left(7^{\text {th }}\right.$ segment or $\left.\mathrm{T}_{7}\right)$ are also calculated.

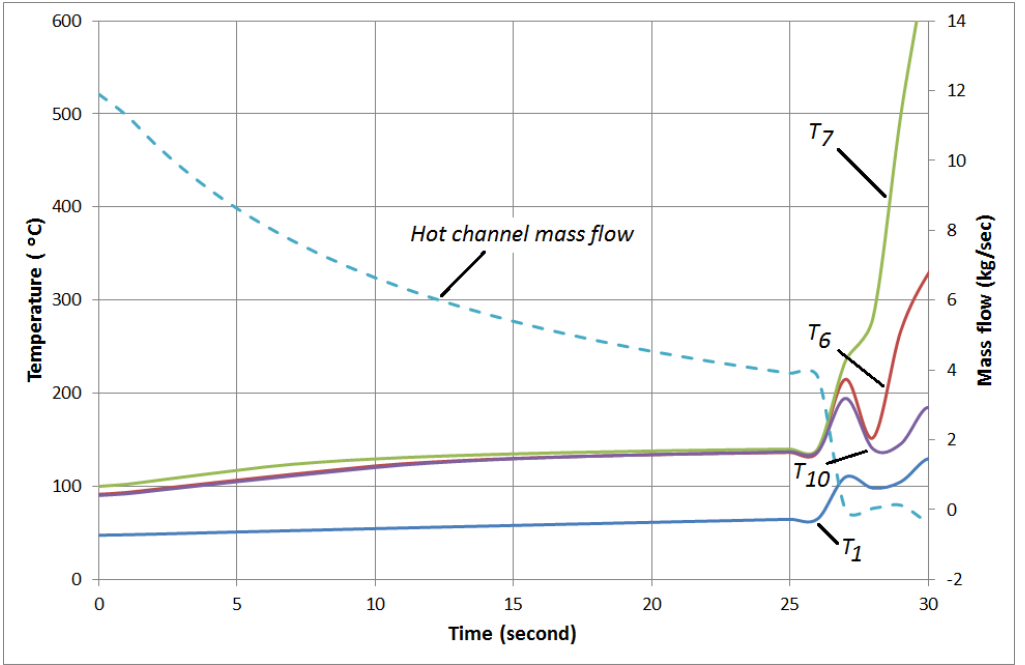

Figure 3. Estimation of cladding temperature in the fuel plates after complete loss of flow event with 30 MWt core power using simplified hot core model

As shown in the Figure 3, the cladding temperature in the hottest axial segment of all 21 fuel plates achieves the cladding melting point around 35 second after loss of flow. Before the sharp temperature increase in $\mathrm{T}=25$ second, the hot channel flow is decreased slowly from $11 \mathrm{~kg} / \mathrm{sec}$ into $4 \mathrm{~kg} / \mathrm{sec}$ when the coolant temperature in the hot channel exceeds the saturation temperature at a particular segment and gas void is formed. The void formation will decrease the heat transfer capability of the coolant to remove heat from the fuel plate as indicated by the sudden temperature increase. [17].The highest increase occurs at the segment with the highest axial peaking factor or $\mathrm{T}_{7}$. The fluctuations occurred during the increase are caused by the reactivity feedback effect included in the RELAP5 input covering the fuel and density reactivity feedback with the nominal RSG-GAS design values. Based on the above results, the cladding temperatures for the other events will be limited only for $\mathrm{T}_{1}, \mathrm{~T}_{7}$, and $\mathrm{T}_{10}$.

\section{Blockage of one or more subchannels on one fuel element with reactor full power without reactor trip}

This event were simulated using the model of 21 fuel plates and 22 subchannel as previously decribed. The scenario is the reactor is operated in nominal full power of $30 \mathrm{MWt}$, when one of 22 subchannel is blocked. The selected blocked subchannel is assumed in the $12^{\text {th }}$ subchannel or between the $11^{\text {th }}$ and $12^{\text {th }}$ fuel plate corresponding to a flow area of $0.0001804 \mathrm{~m}^{2}$. Figure 4 shows the change of cladding temperatures in the hottest segment $\left(\mathrm{T}_{7}\right)$ of 2 fuel plates flanking the blocked subchannel. There are 6 cladding temperatures under consideration, which are on the right side of $11^{\text {th }}$ plate and left side of $12^{\text {th }}$ plate denoted as T-11-right and T-12-left. Those sides are directly in contact with the blocked subchannel. Other 2 cladding temperatures are on the outer sides of those 2 fuel plates denoted as T-11-left and T-12-right. As comparison, other 2 cladding temperatures are calculated in the $10^{\text {th }}$ and $13^{\text {th }}$ plate. 


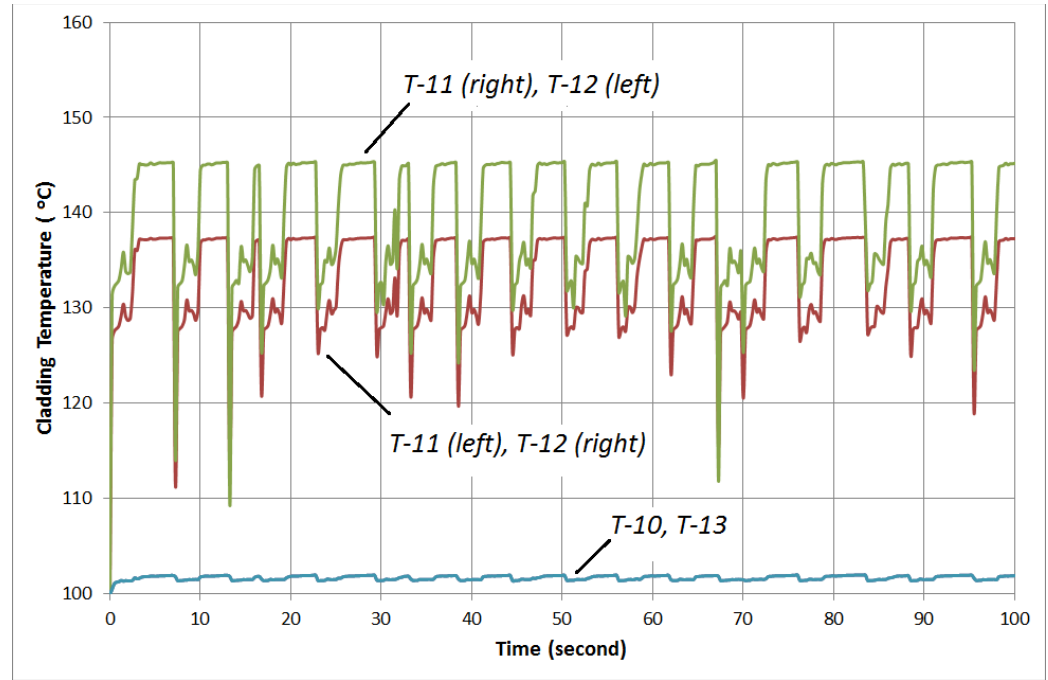

Figure 4. Estimation of cladding temperature in the hottest segment of fuel plates after one subchannel is blocked with $30 \mathrm{MWt}$ core power using the model of 21 fuel plates and 22 subchannel

The figure shows that a blockage of 1 subchannel out of 22 during hot full reactor power did not affect the cladding temperature of the 2 fuel plates flanking the subchannel. The heat generated in the $11^{\text {th }}$ and $12^{\text {th }}$ fuel plate can be transferred in to the other subchannels, which are the $11^{\text {th }}$ and $13^{\text {th }}$ coolant subchannel. From the nominal steady state cladding temperature of around $100{ }^{\circ} \mathrm{C}$ with the normal subchannel cooling (T-10, T-13), there are an increase of the cladding temperature in the sides of the 2 fuel plates (T-11-right) and (T-12-left) that are directly in contact with the blocked subchannel. The other sides of the 2 fuel plates (T-11-left) and (T-12-right) also experience an increase of the cladding temperature even with the less magnitude due to the normal subchannel cooling. The heat generation and removal occurs alternately by the coolant flowing through the unblocked or adjacent subchannels. Such heat transfer of blocked one channel to the adjacent channel has also been demonstrated to not affect the fuel plate temperature in a 10 MW MTR pool type reactor [18]. Based on the results, another simulation is conducted by adding another subchannel blockage, which is in the $13^{\text {th }}$ subchannel. Figure 5 shows the calculated cladding temperature in the hottest segment of fuel plates flanking the $12^{\text {th }}$ subchannel (T-11-right and T-12left) and those of the $13^{\text {th }}$ subchannel (T-12-right and T-13-left) and also the other fuel plates (T-10 and $\mathrm{T}-14)$.

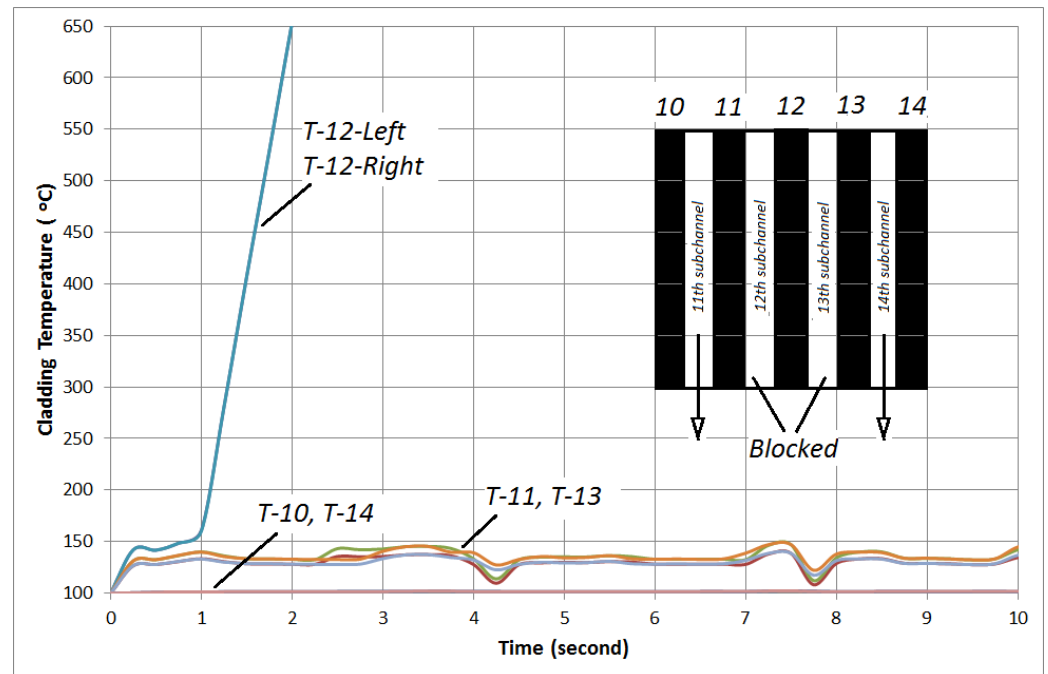

Figure 5. Estimation of cladding temperature in the hottest segment of fuel plates after two subchannels are blocked with $30 \mathrm{MWt}$ core power 
Figure 5 shows that the cladding temperature in the $12^{\text {th }}$ fuel plate measured in the hottest segment experiencing a spike increase to the cladding melting point of $650{ }^{\circ} \mathrm{C}$ around 2 seconds after two subchannels surrounding the plate are blocked. Those temperatures are denoted as T-12-left and T12-right corresponding to the left and right surface plate area. The other sides of the fuel plate only undergo a relative minor increase of the cladding temperature as shown in the right side of the $11^{\text {th }}$ fuel plate and left side of the $13^{\text {th }}$ fuel plate with a relative identical increase. The unchanged cladding temperature can be observed in the $10^{\text {th }}$ and $14^{\text {th }}$ fuel plate. Based on that simulation, a minimum of 2 subchannel blockages can cause a damage in the fuel plate cladding due to the simultaneously loss of cooling in the plate surfaces. Both simulation demonstrated that the reactor can still safely operate with one blocked subchannel in the hottest fuel element and will not harm the clad. More than one blocked subchannel can damage the clad as shown in the high cladding temperature. Those phenomena have been also validated in the Tehran Research Reactor [8] using the same fuel plate model. The presence of void in the blocked subchannels to obstruct the heat transfer to the coolant is also similar with the calculation in the Safety Analysis Report [4]. To confirm the risk of more than 2 blocked subchannels, Figure 6 shows the effect of cladding temperature when all 22 subchannels (complete one fuel element) are blocked during full power. Differences between a number of fuel plates to achieve the cladding melting temperature of $650{ }^{\circ} \mathrm{C}$ need to be further analyzed, which may occur due to interaction among blocked fuel subchannels.

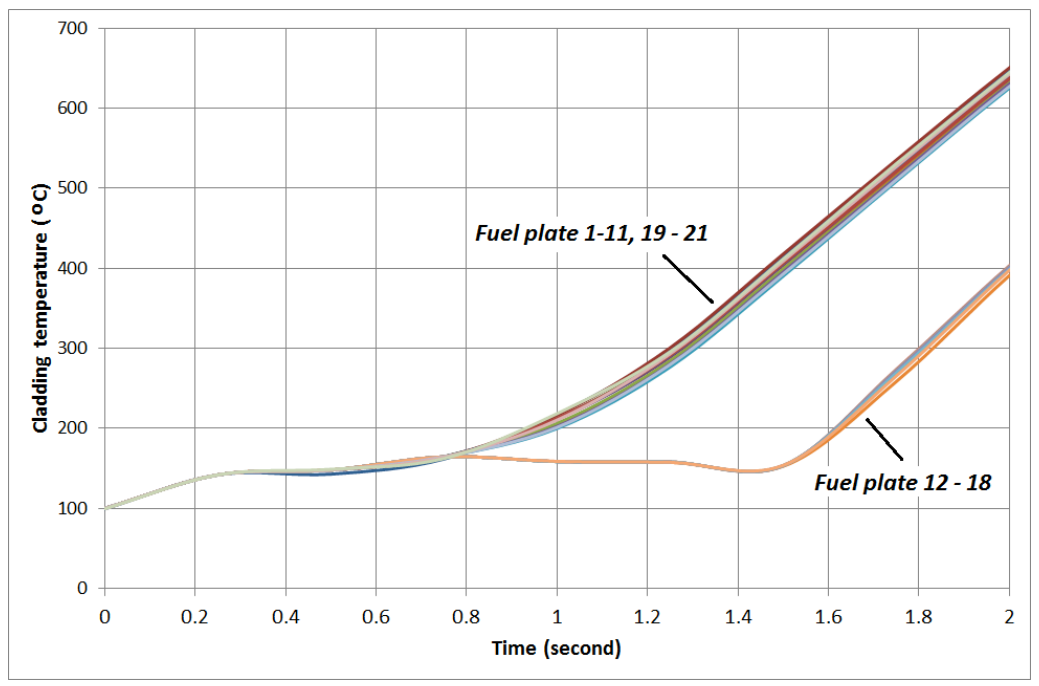

Figure 6. Estimation of cladding temperature in the hottest segment of fuel plates after 22 subchannels are blocked with $30 \mathrm{MWt}$ core power

\section{Blockage of one or more subchannels on one fuel element following loss of complete flow with reactor trip}

This event is initiated by a loss of complete flow during $30 \mathrm{MWt}$ full power followed by a reactor trip. After opening of natural circulation flaps to ensure natural circulation cooling inside the core and 1 hour under shutdown condition, 22 subchannels are assumed to experience a blockage. The event scenario of the loss of complete flow is summarized in Table 3.

Table 3. Sequence of LOFA and reactor trip with fuel channel blockage

\begin{tabular}{ll}
\hline Event & Time or setpoints \\
Steady state simulation of $30 \mathrm{MWt}$ & 1000 seconds \\
Primary and secondary pump trip & 1000.1 seconds \\
Reactor trip & $85 \%$ of nominal primary flow rate \\
Natural circulation flap opens & $129 \mathrm{~kg} /$ second in one primary loop \\
all subchannels in hot core are blocked & 60 minutes after reactor trip \\
End of simulation & 5000 seconds \\
\hline
\end{tabular}


Figure 7 shows that a blockage of all subchannels in the hot core which occurres 1 hour (3600 minutes) after reactor trip does not result in increase of cladding temperature of all fuel plates in to the melting temperature. The resulted time sequences of reactor systems such as scram and natural circulation flap opening time are not the subject of analysis. At the end of simulation, the reactor power has been dropped from $30 \mathrm{MWt}$ to around $300 \mathrm{kWt}$. This low thermal power is related with the low heat generation from the fuel plates during the flow blockage in the hot core. The reversed flow from the bottom to upper core as a natural circulation contributes to the heat removal inside the hot core as showed by the cladding temperature oscillations. Other factors of the fuel plate cooling are the role of the fuel and density reactivity feedback. The highest cladding temperature calculated after subchannel blockages is less than $127{ }^{\circ} \mathrm{C}$ occurred in the segment with the highest axial power peaking factor.

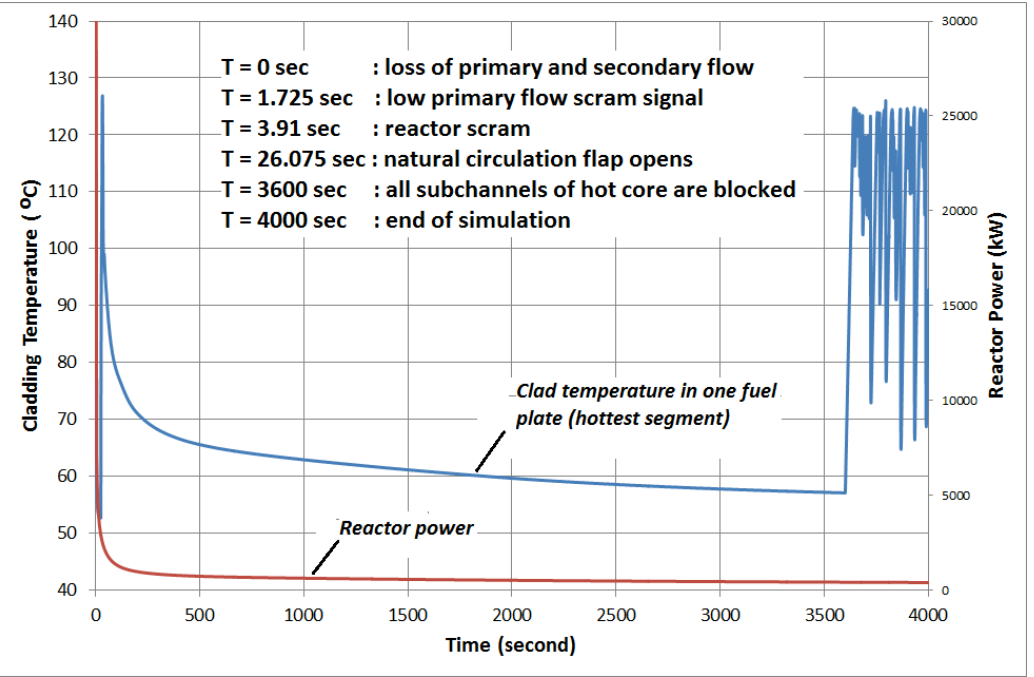

Figure 7. Estimation of cladding temperature after blockage of one fuel element following loss of flow and reactor trip

A similar result is obtained, when the subchannel blockage is set to occur 500 second after reactor trip followed by reactor power achieving $600 \mathrm{kWt}$ at the end of simulation. Based on the simulation, a maximum reactor power level has been obtained in which a blockage of one fuel element is predicted to not harm the integrity of fuel plates under natural circulation condition. The value still requires further validation by different calculation method or best estimate code.

In general, this simulation representing the severe accident at RSG-GAS reactor core is only limited to a specific initial condition, which has been validated by other calculation. The results could not be directly compared with those described in the SAR of RSG-GAS related to the event of blockage of one fuel element [4], but they can confirm the analysis performed in the SAR. In the SAR, the blockage of the one fuel element was conducted under assumption of $114 \%$ reactor power and higher radial power peaking factor of 2.6. Those values are very conservative, higher than this simulation, whereas this calculation used a best-estimate approach with best-estimate initial conditions validated with other codes, at least at the steady-state condition.

\section{CONCLUSION}

Severe accidents leading to a damage of fuel plates have been simulated in the RSG-GAS reactor. Using the RELAP5 thermalhydraulic code, three events which are assumed to occur in the reactor have delivered different effects on the integrity of fuel plates under certain boundary condition. The capability of RELAP5 to model individual fuel plates in the RSG-GAS core has helped to predict the effect of loss of cooling on each fuel plate. The first event involving loss of primary and secondary flow with the failure of reactor to scram will harm the fuel plate cladding as showed by its melting temperature of $650{ }^{\circ} \mathrm{C}$. The second event related to blockage of one or more 
subchannels in the one fuel element results in different consequences to the fuel plate, in which at least two blocked subchannels will damage one fuel plate, even more the blockage of one fuel element during full reactor power. The last event is the combination of loss of primary and secondary flow followed by reactor trip and blockage of one fuel element has provided an increase of fuel plate temperature below its melting point meaning that the established natural circulation and the relative low reactor power is sufficient to cool the fuel element. A maximum reactor power level has been obtained in which a blockage of one fuel element is predicted to not harm the integrity of fuel plates under natural circulation condition, which requires further validation by different calculation method or best estimate code.

\section{ACKNOWLEDGEMENT}

This work was fully funded by BATAN research project (DIPA) of the year 2017, which was managed by Center for Nuclear Reactor Safety and Technology (PTKRN). The author is very thanksful to Mr. Surip Widodo for his valuable assistance and discussion during the analysis of calculation results and Center for Multipurpose Reactor for providing necessary document for comparison purposes.

\section{REFERENCES}

1. Seo CG., Cho NZ. A core design concept for multi-purpose research reactors. Nucl. Eng. Des. 2012; 252: $34-41$.

2. Zeggar F., Belgaid M., Zidi T. Estimating of core inventory, source term and doses results for the NUR research reactor under a hypothetical severe accident. Prog. Nucl. Energy 2017; 100: 365-372.

3. Chusov IA., Shelegova AS., Kochnov Y. Design features of water-cooled research reactors. Nucl. Energy Technol. 2016; 2: 287-293.

4. BATAN. Laporan Analisis Keselamatan (LAK) RSG-GAS Rev. 10.1. Badan Tenaga Nuklir Nasional; December 2011. Dokumen No. RSG.KK.01.63.11 (in Indonesian).

5. Hastuti EP. Analisis LOFA teras alternatif silisida 4,8g U/cc RSG-GAS menggunakan PARET-ANL. in: Prosiding Pertemuan dan Presentasi Ilmiah Penelitian Dasar Ilmu Pengetahuan dan Teknologi Nuklir. Yogyakarta. 2007 (in Indonesian).

6. Ekariansyah AS., Susyadi, Dibyo S. Aplikasi program RELAP5/Mod3.2 untuk simulasi beam tube rupture RSG-GAS. Tri Dasa Mega 2006; 8 (3): 114 - 125.

7. Hastuti EP, Kaminaga M. Analisis kecelakaan penyumbatan parsial kanal pendingin elemen bakar pada teras oksida dan disain teras silisida RSG GAS. In: Prosiding Pertemuan dan Presentasi Ilmiah. Yogyakarta. 1999 (in Indonesian).

8. Tabbakh F. Effects of cooling channel blockage on fuel plate temperature in Tehran Research Reactor. Nucl. Sci. Tech. 2009; 20: 184-187.

9. Lee KY., Kim WS. Theoretical study on loss of coolant accident of a research reactor, Nucl. Eng. Des. 2016; 309: 151-160.

10. Abdelrazek ID., Naguib Aly M., Badawi AA., Abo Elnour AG, Benchmarking RSG-GAS reactor thermal hydraulic data using RELAP5 code. Ann. Nucl. Energy 2014; 70: 36-43.

11. Subekti M., Darwis I., Hastuti EP. Analisis distribusi kecepatan pendingin dalam elemen bakar tipe pelat menggunakan metode CFD untuk reaktor riset RSG-GAS. Tri Dasa Mega 2013; 15(2): 67-76.

12. Chatzidakis S., Hainoun A., Doval A., Alhabet F., Francioni A., Ikonomopoulos A., Ridikas D., A comparative assessment of independent thermal-hydraulic modelsfor research reactors: the RSG-GAS case. Nucl. Eng. Des. 2014; 268: 77- 86.

13. Pinem S., Liem PH., Sembiring TS., Surbakti T. Fuel element burnup measurements for the equilibrium LEU silicide RSG GAS (MPR-30) core under a new fuel management strategy. Ann. Nucl. Energy 2016; 98: 211-217. 
14. Karimpour M., Esteki MH. Loss of coolant accident analyses on multi purpose research reactor by RELAP5/MOD3.2 code. Prog. Nucl. Energy 2015; 79: 158-166.

15. Chatzidakis S., Ikonomopoulos A., Ridikas D. Evaluation of RELAP5/MOD3 behavior against loss of flow experimental results from two research reactor facilities. Nucl. Eng. Des. 2013; 255: 321- 329.

16. Ginting $\mathrm{AB}$. Analisis termal paduan $\mathrm{AlMgSi}$ untuk kelongsong bahan bakar $\mathrm{U}_{3} \mathrm{Si}_{2}-\mathrm{Al}$ densitas tinggi. Urania 2010; 16 (2): 47 - 104.

17. Iliuk I., Balthazar JM., Tusset AM., Piqueira JRC. Thermal-hydraulic analysis of a platetype fuel surrounded by two water channels by using RELAP5, Math. Eng. Sci. Aerospace 2015; 6 (3): 507 - 517.

18. Lu Q., Qiu S., Su GH. Flow blockage analysis of a channel in a typical material test reactor core. Nucl. Eng. Des. 2009; 239: 45 - 50. 